\title{
The Effect of Brazilin from Caesalpinia sappan on Cell Cycle Modulation and Cell Senescence of T47D Cells
}

\author{
Riris Istighfari Jenie ${ }^{1,2 *}$, Sri Handayani²,3, Ratna Asmah Susidarti1,2, Edy Meiyanto ${ }^{1,2}$
}

1. Department of Pharmaceutical Chemistry, Faculty of Pharmacy, Universitas Gadjah Mada, Sekip Utara Yogyakarta 55281, Indonesia.

2. Cancer Chemoprevention Research Center, Faculty of Pharmacy, Universitas Gadjah Mada, Sekip Utara Yogyakarta 55281, Indonesia.

3. Research Division for Natural Product Technology, Indonesian Institute of Sciences (LIPI), Gading, Playen, Gunungkidul, DIY, Indonesia

\begin{tabular}{|c|c|}
\hline Info & \multirow{19}{*}{ 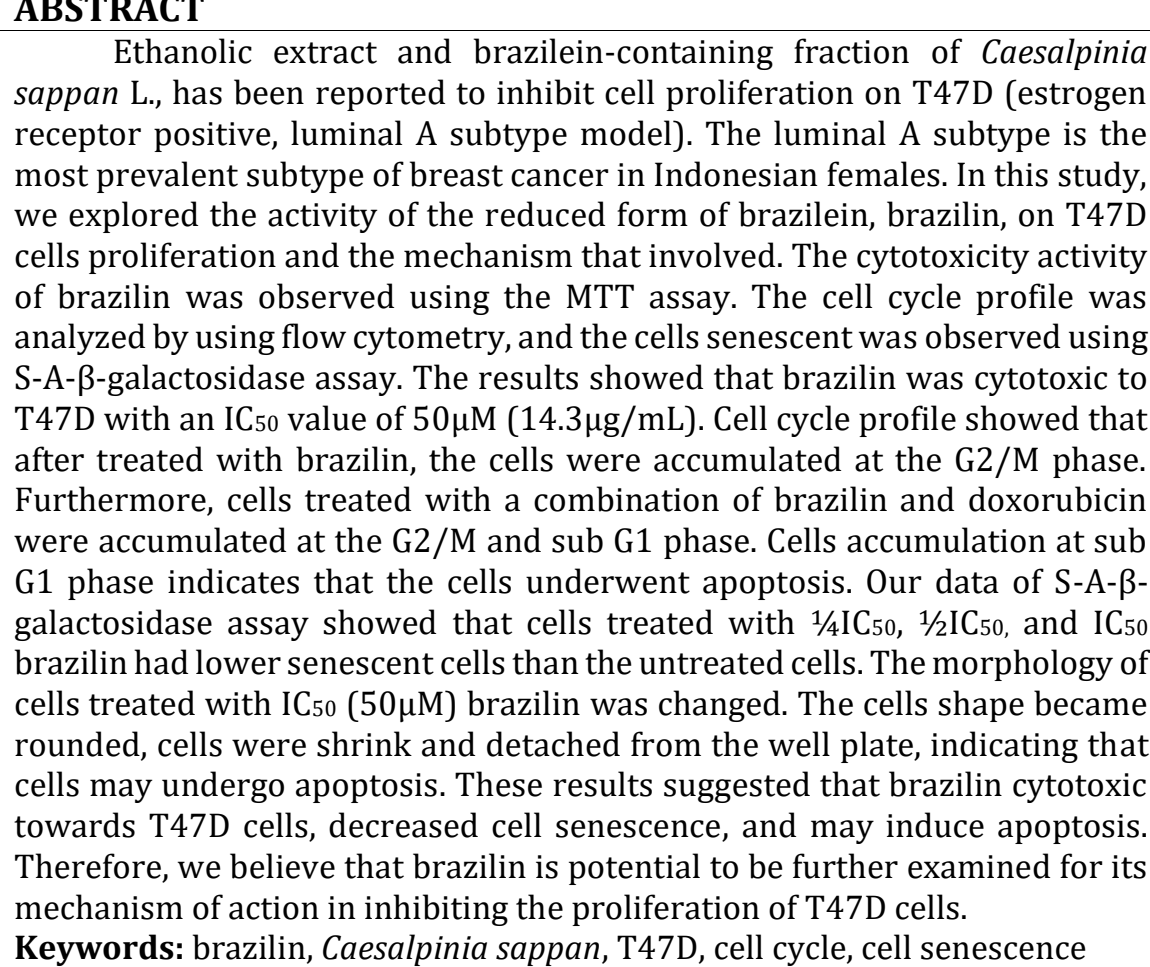 } \\
\hline Submitted: $19-10-2019$ & \\
\hline Revised: 29-01-2020 & \\
\hline Accepted: 02-03-2020 & \\
\hline${ }^{*}$ Corresponding author & \\
\hline Riris Istighfari Ienie & \\
\hline & \\
\hline & \\
\hline & \\
\hline & \\
\hline & \\
\hline & \\
\hline & \\
\hline & \\
\hline & \\
\hline & \\
\hline & \\
\hline & \\
\hline & \\
\hline
\end{tabular}

\section{INTRODUCTION}

Breast cancer is the most prevalent cancer in women around the globe, including in Indonesia. Based on the data of Globocan 2018, breast cancer positioned in the first rank of cancer incidence and mortality-causing cancer in Indonesian women (Global Cancer Observatory, 2018). The luminal A $\left(\mathrm{ER}^{+} \mathrm{PR}^{+/-} \mathrm{HER} 2^{-}\right)$subtype is the most prevalence of breast cancer in Indonesia (Rahmawati et al, 2017). Cancer cells must evade programs that negatively regulate cell proliferation to maintain their growth. Cancer cells with mutated or non-functional of tumor suppressor genes are thus missing a crucial checkpoint of cell-cycle progression, implicating in the cell over-proliferation (Hanahan and Weinberg,
2011). There is another mechanism known to halt cell proliferation besides apoptosis (programmed cell death), named cellular senescence. Cellular senescence is one of cellular homeostasis mechanism as a response to cellular stress that is defined as a permanent cell cycle arrest (Childs et al., 2014; Myrianthopoulos et al., 2019). Senescence now becomes a target in cancer control. It was first explained in 1961, by Hayflick and Moorhead, as a replicative senescent triggered by telomere attrition (Childs et al., 2014). Currently, it is known that senescence could be triggered by various extrinsic factors, including conventional chemotherapeutic agents, oxidative stress, and genetic manipulations as well. This form of 
senescence was termed as stress-induced premature senescence (Myrianthopoulos et al., 2019), and this can be induced in tumor cells (Roninson, 2003).

It was suggested by Uchida et al (2013) that the application of chemotherapy on patients with luminal A breast cancer may bring patients longer relapse-free periods. However, the cytotoxicity of chemotherapeutic agents such as cis-platinum, paclitaxel, cyclophosphamide, 5-fluorouracil, and doxorubicin (Dox) is not limited to cancer cells but also affected normal tissue (Tiwari et al., 2011). The drawback leads to the development of natural compounds present in the nutrition as these phytochemicals have been displayed a chemoprevention and anticancer effects. Most of the phytochemicals are nontoxic compared to chemotherapeutic agents (Tiwari et al., 2011). C. sappan (Sappan wood; local name in Indonesia is "Secang") is a well-known herbal plant in Southeast Asia (Nirmal et al., 2015). Previously our group observed that the ethanolic extract of $C$. sappan induced apoptosis in T47D (a luminal A model breast cancer cell line) cells and had a synergistic effect with doxorubicin in inhibiting the growth of the cells (Nurzijah et al., 2012). Brazilin and brazilein are two major bioactive compounds of $C$. sappan. The brazilein-containing fraction of $C$ sappan L., has been reported to inhibit cell proliferation on T47D (Tirtanirmala et al, 2015). Therefore, it is important to clarify the potency of brazilin on the luminal A model breast cancer cell line. In this report, we studied the significance of brazilin from $C$. sappan in inhibiting proliferation of T47D cells as a model of Luminal A subtype breast cancer. Furthermore, as T47D carries mutated and non-functional form of $p 53$ (Mumcuoglu et al., 2010), a critical suppressor gene that regulates cell cycle checkpoints, apoptosis, and senescence (Speirs et al., 2011), we analyzed brazilin effect on cell cycle modulation and cell senescence as one of mechanisms that halt cell proliferation.

\section{MATERIAL AND METHODS Chemicals}

Brazilin was isolated from C. sappan, L. using the previously reported method (Jenie et al., 2018). Doxorubicin was purchased from Harlem (The Netherlands, imported by Combiphar, Indonesia).

\section{Cell culture}

The T47D cell line was a collection of Cancer Chemoprevention Research Center (CCRC), Faculty of Pharmacy, Universitas Gadjah Mada, which was given by Prof. Dr. Masashi Kawaichi (Nara Institute of Science and Technology, Japan). Cells were grown in Dulbecco's modified Eagle's medium (DMEM) (Thermo Fisher Scientific, Waltham, MA) with $10 \%$ fetal bovine serum (FBS) (Thermo Fisher Scientific), and $1 \%$ penicillin-streptomycin (Thermo Fisher Scientific).

\section{Cytotoxicity assay}

The T47D cells $\left(1 \times 10^{4} /\right.$ well $)$ in 96-well plates were treated with brazilin at $5-100 \mu \mathrm{M}$. The sample was prepared at concentration $5 \mathrm{mg} / \mathrm{mL}$ $(17 \mu \mathrm{M})$ with a dimethyl sulfoxide (DMSO) as cosolvent, and then diluted in DMEM cell culture medium. Cells were incubated for $24 \mathrm{~h}$ at $37^{\circ} \mathrm{C}$ and $5 \% \mathrm{CO}_{2}$, then cells were washed in phosphatebuffered saline (PBS) (Sigma-Aldrich). Cells were incubated with $5 \mathrm{mg} / \mathrm{mL}$ MTT reagent (SigmaAldrich) for $4 \mathrm{~h}$ then the reaction was stopped using $10 \%$ sodium dodecyl sulfate (SDS) in $0.01 \mathrm{M} \mathrm{HCl}$ (Millipore Sigma) overnight. The absorbance was measured at $595 \mathrm{~nm}$. The results were presented as a percentage of cell viability. The concentration of sample that inhibited $50 \%$ of cell viability of the control DMEM ( $\left.\mathrm{IC}_{50}\right)$ was calculated from three independent experiments in triplicate.

\section{Cell cycle analysis}

The T47D cells $\left(5 \times 10^{4}\right.$ cells/well $)$ were grown in the 24-well plate, treated with various concentrations of samples (brazilin and doxorubicin) for $24 \mathrm{~h}$. Cells were then harvested, fixed with $70 \%$ ethanol and stained with propidium iodide (PI)/RNAse staining kit (BD Biosciences, San Jose, CA) to analyze the DNA content using flow cytometry (BD Biosciences Accuri C6) and BD Accuri C6 software.

\section{Senescence-associated $\boldsymbol{\beta}$-galactosidase assay}

Senescence-associated $\beta$-galactosidase (SA$\beta$-gal assay) was used to observe the senescent cell. The method was performed as previously described (Hanif et al., 2019). Briefly, T47D cells were grown at $1 \times 10^{4}$ cells in 6 -well plate and treated with samples (brazilin and doxorubicin) for $24 \mathrm{~h}$. Cells were washed and fixed then incubated in staining solution for $48 \mathrm{~h}$ at $37^{\circ} \mathrm{C} \quad \mathrm{CO}_{2}$ free. Cells were observed using an inverted microscope (Olympus CKX41) at 100x magnification. The $\beta$-D-galactosidase positive cells were quantified using ImageJ software. The results were presented as a percentage of senescent cell, which was calculated from positive cells compared to the total cell number in one observing field. 

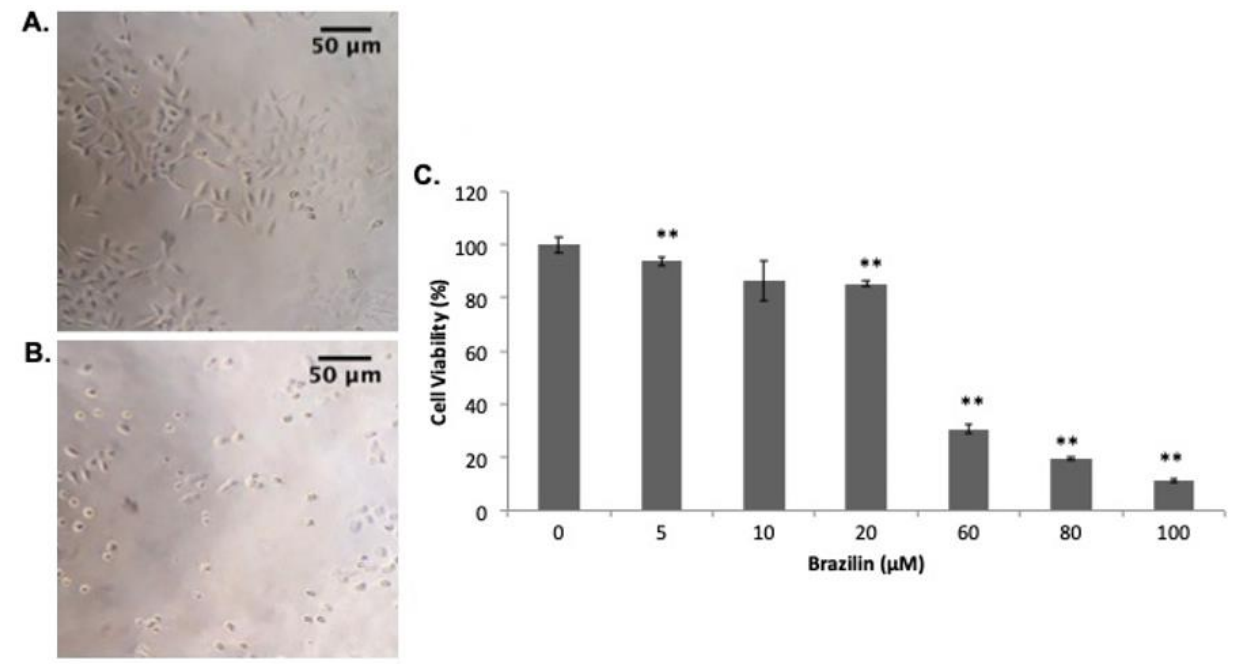

Figure 1. Cytotoxic activity of brazilin on T47D cells. Cells morphology after treatment of untreated (A) and $60 \mu \mathrm{M}$ brazilin (B). Percentage of T47D cell viability after samples treatment (C). Cells were treated with 5$100 \mu \mathrm{M}$ of brazilin for $24 \mathrm{~h}$ before assessed by MTT assay. Error bar represents the standard deviation from three independent experiments. ${ }^{* *} P<0.01$.

We performed calculation from three different observing fields from each experiment.

\section{Data analysis}

All data were expressed as means \pm SD or SE. Statistical analysis of the experimental data was conducted by using Student's t-test (Excel 2013 software; Microsoft, Redmond, WA). $P$ values of less than 0.05 or 0.01 were considered to be significant.

\section{RESULTS AND DISCUSSION \\ Cytotoxicity of brazilin on T47D cells}

Our group has reported the cytotoxicity of ethanolic extract of $C$. sappan on T47D with the $\mathrm{IC}_{50}$ value of $35 \mathrm{ug} / \mathrm{mL}$ (Nurzijah et al., 2012). T47D cells viability was decreased after treatment of brazilin for $24 \mathrm{~h}$ in a dose-dependent manner (Figure 1). Cell morphology was changed under treatment of brazilin. The increased brazilin concentration caused shrinkage of the cells, cells round shape, and detached from the culture plate (Figure 1 A-D). These morphology changes were suggested to be the characteristics of cells that undergo apoptosis (Saraste and Pulkki, 2000).

\section{Cell cycle modulation of brazilin on T47D cells}

The cell proliferation relies on the cell cycle progression. Thus, we investigated the outcome of brazilin on cell cycle modulation (Figure 2). We used doxorubicin (Dox) as a positive control because Dox is a chemotherapeutic agent that is known to induce G2/M arrest in T47D cells (Meiyanto et al., 2011). The IC50 of Dox on T47D was 50nM, according to Jenie and Meiyanto (2007). We confirmed that Dox (25 and 50nM) halt the T47D cell cycle progression at G2/M phase (Figure 2D,E). Meanwhile, we observed that brazilin caused cell accumulation at G2/M phase and increased sub G1 population in a dose-dependent manner (Figure 2B-2C). Cells that were given with the combination of $1 / 2 \mathrm{IC}_{50}$ brazilin $(25 \mu \mathrm{M})$ and $1 / 2 \mathrm{IC}_{50}$ doxorubicin $(25 \mathrm{nM})$, were accumulated at $\mathrm{G} 2 / \mathrm{M}$ phase and sub G1 phase, increased around $25 \%$ and $10 \%$, respectively, compared to untreated cells (Figure 2E).

\section{Brazilin effect on cellular senescence of T47D}

T47D is a well-known breast cancer cell with mutated and non-functional $p 53$ (Mumcuoglu et al., 2010). The p53 protein is a critical controller of cell cycle checkpoints, apoptosis, and senescence (Speirs et al., 2011). Therefore, we conducted an S-A- $\beta$-galactosidase assay to assess the effect of brazilin on T47D cellular senescence. The results showed that untreated T47D contained $30 \%$ senescent cells as quantified in the graph (Figure 3A, G). The senescent cells in the untreated cells may be related to the fact that tumor cell senescence could develop spontaneously in response to the environment changes. 
A.
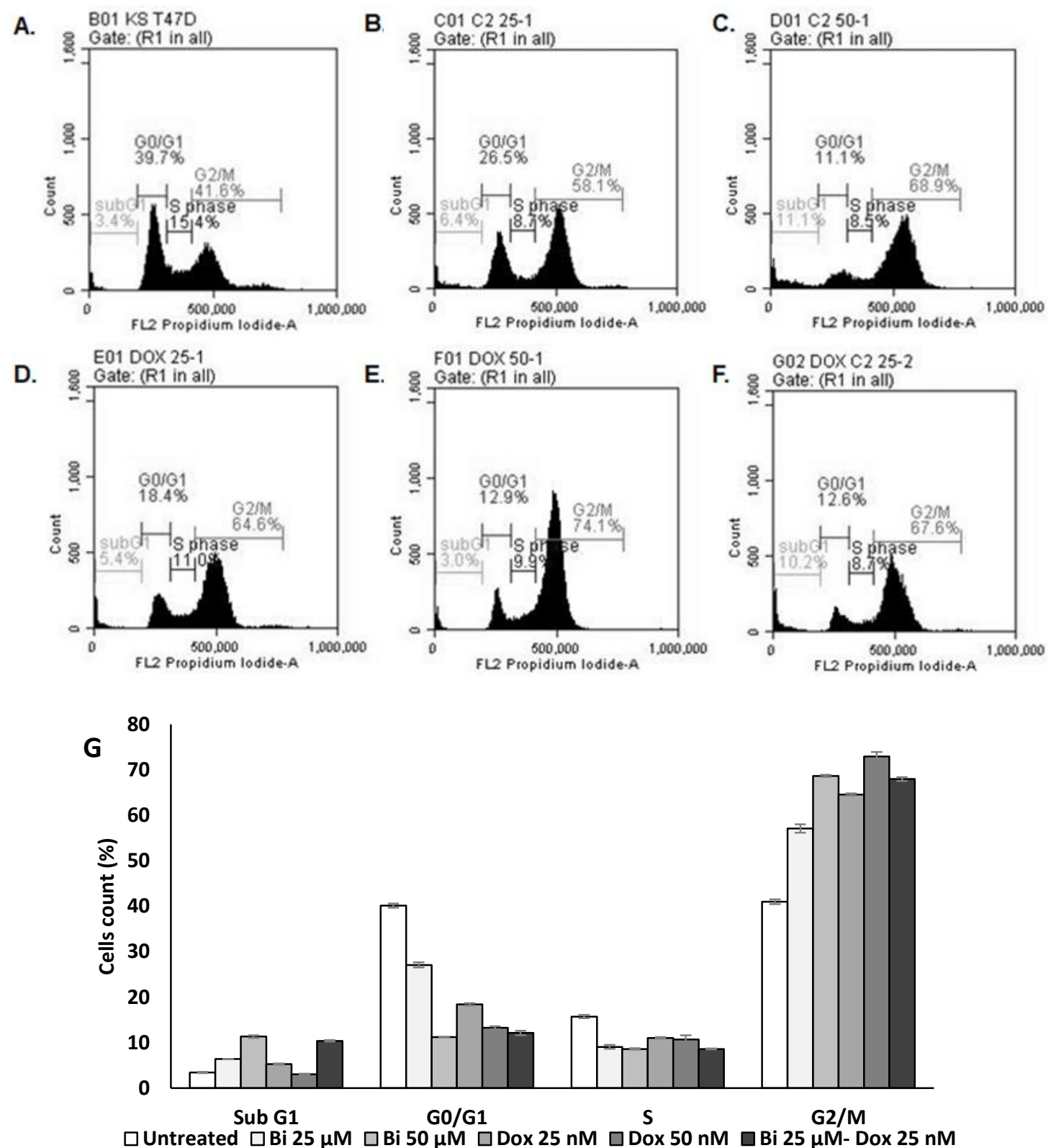

Figure 2. The effect of brazilin on T47D cell cycle profiles. Histogram profile of T47D cells after treated with

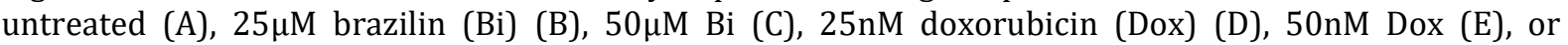
combination of $25 \mu \mathrm{M}$ Bi and $25 \mathrm{nM}$ Dox (F) for $24 \mathrm{~h}$, then stained with PI/RNase for cell cycle analysis. (G) Cell cycle profile of T47D cells. The analysis of the cell cycle was conducted using flow cytometry as described in the Materials and Methods. Error bar represents the standard error from three experiments.

The senescent cell was observed in approximately $20 \%$ of the tumor cells, even without drug treatment (Roninson, 2003). Moreover, according to a study by Mumcuoglu et al. (2010), T47D cells were categorized into senescent cell progeny (SCP) due to their capability to generate senescent progeny in a low-density clonogenic circumstances.
As cell senescence could be induced by treatment of chemotherapeutic agents (Roninson, 2003), we treated the cells with Dox to compare it with brazilin. Our study showed that 10nM Dox increased $20 \%$ of senescent cells compared to untreated cells (Figure 3B,G). In contrast, 50nM Dox decreased senescent cells until less than $10 \%$ 

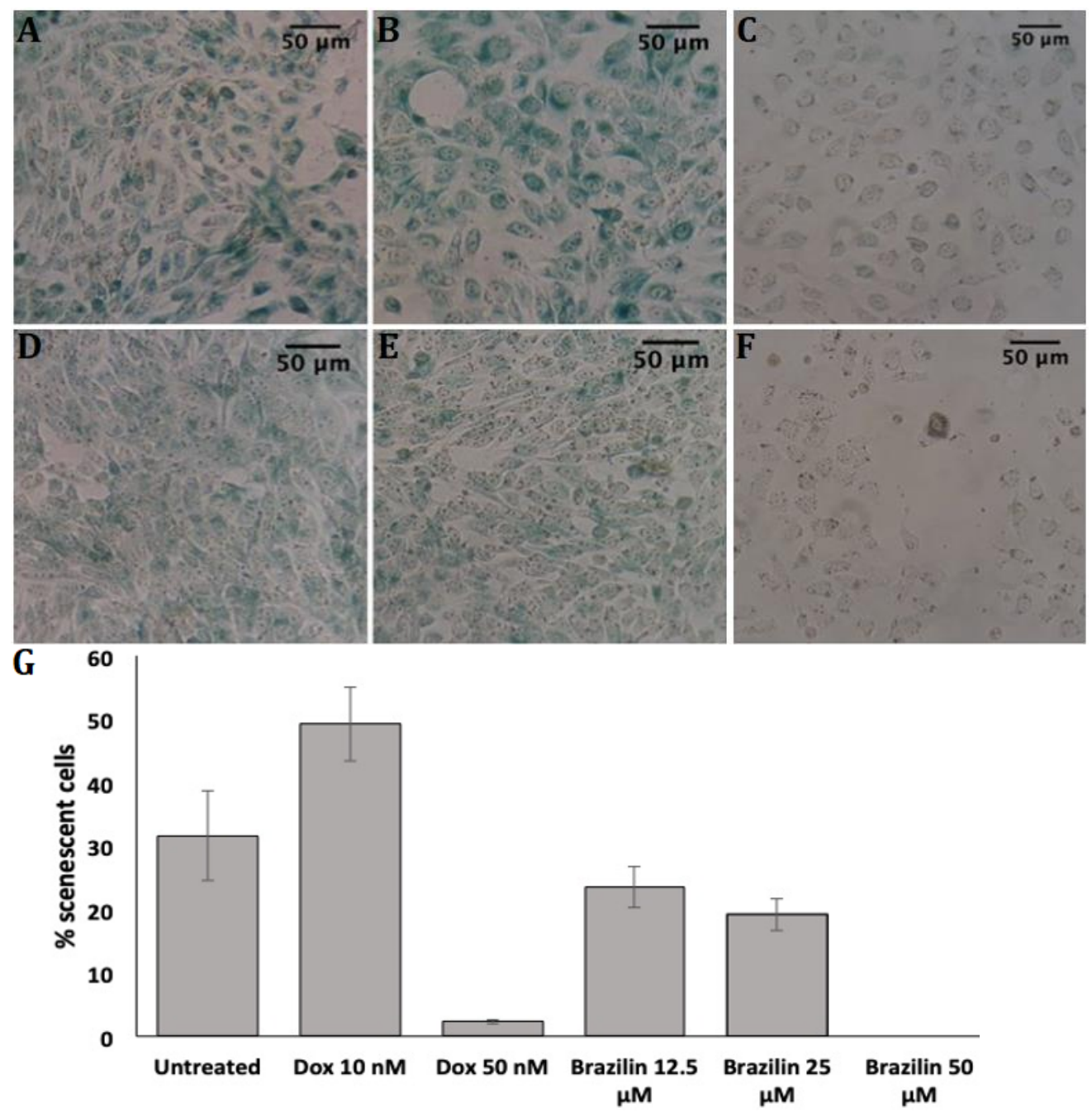

Figure 3. The effect of brazilin on T47D cellular senescence. T47D cells were grown at $1 \times 10^{4}$ cells, except the untreated (A), the cells were then treated for $24 \mathrm{~h}$ with $10 \mathrm{nM}$ doxorubicin (Dox) (B), 50nM Dox (C), $12.5 \mu \mathrm{M}$ brazilin (Bi) (D), $25 \mu \mathrm{M}$ Bi (E), and $50 \mu \mathrm{M} \mathrm{Bi} \mathrm{(F).} \mathrm{Cells} \mathrm{were} \mathrm{then} \mathrm{stained} \mathrm{by} \mathrm{the} \mathrm{substrate} \mathrm{solution} \mathrm{of}$ the senescence-associated $\beta$-galactosidase for $48 \mathrm{~h}$ resulting in blue-green color cells. Senescence evidence was monitored by an inverted microscope in 100x magnification and quantified as described in the Materials and Methods (G). Error bar represents the standard error of quantification from three observing fields.

(Figure 3C,G). These data were indicating that the concentration of the chemotherapeutic agent determined cell fate. At low concentration, Dox was reported to induce intracellular the reactive oxygen species (ROS) level and sensecence (Hanif et al., 2019; Meiyanto et al., 2018). Low concentration of Dox was reported to promote senescence in SKN-SH neuroblastoma and colorectal carcinoma cells, associated with high $p 21$ expression, whereas high concentration of Dox resulted in low p21 expression and apoptosis (Childs et al., 2014). Moreover, brazilin (at $1 / 4$ IC $_{50}$,
$1 / 2 \mathrm{IC}_{50}$, and $\mathrm{IC}_{50}$ ) reduced cell senescence in a dose dependent manner (Figure 3D-3G). Brazilin at $1 / 4$ IC 50 decreased cell senescence by $10 \%$ compared to the untreated and at $\mathrm{IC}_{50}$, the senescent cells were very low, similar to that upon 50nM Dox.

In the current study, we evaluated the anti proliferation of brazilin against T47D cell line. The MTT assay demonstrated that brazilin was cytotoxic with an $\mathrm{IC}_{50}$ value of $14.3 \mu \mathrm{g} / \mathrm{mL}(50 \mu \mathrm{M})$ (Figure 1E). The value was lower than the $\mathrm{IC}_{50}$ of the ethanolic extract of $C$. sappan and the brazileincontaining fraction on the same cell line which 
were $35 \mu \mathrm{g} / \mathrm{mL}$ and $68 \mu \mathrm{g} / \mathrm{mL}$, respectively (Nurzijah et al., 2012; Tirtanirmala et al., 2015). Brazilin and brazilein are the major components of C. sappan with a similar structure. Moreover, brazilein is the oxidized form of brazilin (Rondão et al., 2013). The lower $\mathrm{IC}_{50}$ value of brazilin compared to brazilein, indicating that brazilin was more potent than brazilein against T47D cells. The capability of brazilin to reduce the growth of other cancer cell type was observed by our group. The $\mathrm{IC}_{50}$ of brazilin in WiDr and MCF-7/HER-2 were 41 $\mu \mathrm{M}$ and $54 \mu \mathrm{M}$, respectively (Handayani et al., 2017; Jenie et al., 2018). However, brazilin was also reported to be cytotoxic against normal fibroblast cells (NIH 3T3 and MEF) (Lee at al., 2015), suggesting a consideration on brazilin selectivity.

Based on the cell cycle analysis we observed that brazilin caused cell accumulation on subG1 and G2/M phase (Figure 2B,C). The sub G1 phase population is often related to apoptotic cells, as one of the apoptotic characteristics is DNA fragmentation, which results in a reduced content of DNA (Studencka and Schaber, 2017). This result was suggesting that the cells were directed into apoptosis via G2/M arrest. The ethanolic extract of C. sappan has already reported inducing apoptosis up to $60 \%$ in T47D cells compared to untreated cells by Nurzijah et al. (2012). Other researchers also reported that brazilin also induced G2/M arrest on several other cancer cell types including U266 cells, WiDr, and MCF-7/HER2 (Kim et al., 2012; Handayani et al., 2017; Jenie et al., 2018). Kim et al. (2012) suggested that the mechanism underlies $\mathrm{G} 2 / \mathrm{M}$ arrest by brazilin involving increased the level of cyclin-dependent kinase (CDK) inhibitor, particularly the p21 and p27 in a time-dependent manner. As a result, the level of cyclin B1 and E were reduced after 24 or $48 \mathrm{~h}$ of brazilin treatment and stimulated the regulator proteins of G2 checkpoint, Chk1 and Chk2, in U266 cells.

In the present study, we observed that brazilin reduced cell senescence in a dosedependent manner (Figure 3D-3G). Previous work from our group reported that treatment of ethanolic extract of $C$. sappan on 4T1 cells gave nonsignificant cell senescence compared to untreated cells (Hanif et al., 2019). Furthermore, according to that study, ROS level of 4T1 cells treated with brazilin was decreased. The addition of ethanolic extract of $C$. sappan on Dox or hydrogen peroxide treated cells was reported to significantly decrease the intracellular ROS level compared to the single treatments of Dox or hydrogen peroxide on $\mathrm{CHO}$ -
K1 cells (Meiyanto et al., 2018). ROS is known as one of the inducers of cell senescence (Myrianthopoulos et al., 2019). High level of ROS plays a vital role in inducing and maintaining cell senescence (Davalli et al., 2016).

Many reports suggested the antioxidant activity of $C$. sappan and its constituents, as reviewed by Nirmal et al. (2015). Amongst other compounds from Sappan lignum, brazilin exhibited the utmost DPPH radical scavenging activity and ferric reduction activity and it is even higher compared to standard vitamin E (Sasaki et al., 2007). Furthermore, $C$. sappan extract and brazilin were also known to scavenge UVA-induced secretions of hydrogen peroxide and increase the expression of the glutathione peroxidase 7 (GPX7) enzyme (Hwang and Sim, 2018). Thus, we suggest that the decreased cell senescence under brazilin treatment was being attributed to its activity as an antioxidant which causing the level of ROS was not high enough to induce cell senescent. However, this hypothesis needs to be further clarified by measuring the ROS level and observing the expression level of antioxidant enzymes in T47D cells under treatment of brazilin.

\section{CONCLUSION}

Our current study revealed that in T47D cells, as a model of Luminal A subtype breast cancer, brazilin was cytotoxic and induced cell cycle arrest at $\mathrm{G} 2 / \mathrm{M}$ phase and possibly directed cells to undergo apoptosis as indicated by the increasing cell population at sub G1 phase. We also demonstrated that brazilin decreased cell senescence in a dose-dependent manner.

\section{ACKNOWLEDGEMENTS}

We thank The Ministry of Research and Technology, Higher Education, the Republic of Indonesia who provides the grant under the PDUPT program, second-year (2019), number 2533/UN1.DITLIT/DIT-LIT/LT/2019.

We also greatly thank Dr. Sari Haryanti from Medicinal Plant and Traditional Medicine Research and Development Centre, Ministry of Health, Indonesia for providing facilities of some experiments in this study.

\section{REFERENCES}

Childs BG., Baker DJ., Kirkland JL., Campisi J., Deursen, JM. 2014. Senescence and apoptosis: dueling or complementary cell fates? EMBO Reports, 15(11), 1139-1153. 
Davalli P., Mitic T., Caporali A., Lauriola A., D'Arca, D. 2016. ROS, Cell Senescence, and Novel Molecular Mechanisms in Aging and AgeRelated Diseases. Oxidative Medicine and Cellular Longevity, 2016 (Article ID 3565127).

Global Cancer Observatory. September 2018. The GLOBOCAN database 2018. International Association of Cancer Registries, (online), (https://gco.iarc.fr/today/data/factsheets/ populations/360-indonesia-fact-sheets.pdf, accessed 7 Mei 2019).

Hanahan D. Weinberg RA. 2011. Hallmarks of Cancer: The Next Generation. Cell, 144, 646674.

Handayani S., Susidarti RA., Jenie RI., Meiyanto E. 2017. Two Active Compounds from Caesalpinia sappan L. in Combination with Cisplatin Synergistically Induce Apoptosis and Cell Cycle Arrest on WiDr Cells. Adv. Pharm. Bull., 7, 375-380.

Hanif N., Hermawan A., Meiyanto E. 2019. Caesalpinia sappan L. Ethanolic Extract Decrease Intracellular ROS Level and Senescence of 4T1 Breast Cancer Cells. Indonesian J Cancer Chem, 10(1), 16.

Hwang HS. Shim JH. 2018. Brazilin and Caesalpinia sappan L. extract protect epidermal keratinocytes from oxidative stress by inducing the expression of GPX7. Chinese Journal of Natural Medicines, 16(3), 203-209.

Jenie RI., Meiyanto E. 2007. Co-chemotherapy of sambung nyawa (Gynura procumbens (Lour.) Merr.) leaves ethanolic extract and Doxorubicin on breast cancer cell. Indonesian Journal of Pharmacy, 18(2), 8187.

Jenie RI., Handayani S., Susidarti RA., Udin LZ., Meiyanto E., 2018. The Cytotoxic and Antimigratory Activity of BrazilinDoxorubicin on MCF-7/HER2 Cells. Adv. Pharm. Bull., 8, 507-516.

Kim B., Kim Sun-Hee, Jeong, S-J., Sohn EJ., Jung JH., Lee MH., Kim SH. 2012. Brazilin Induces Apoptosis and G2/M Arrest via Inactivation of Histone Deacetylase in Multiple Myeloma U266 Cells. J. Agric. Food Chem, 60 (39), 9882-9889.

Lee H., Kang SW., Byun, HS., Jeon J., Park KA., et al., 2015. Brazilin limits inflammatory responses through induction of prosurvival autophagy in rheumatoid fibroblast-like synoviocytes. PLOS ONE, 10(8), 1-15.
Meiyanto E., Fitriasari A., Hermawan A., Junedi S., Susidarti RA. 2011. The improvement of doxorubicin activity on breast cancer cell lines by tangeretin through cell cycle modulation. Oriental Pharmacy and Experimental Medicine, 11(3), 183-190.

Meiyanto E., Lestari B., Sugiyanto, R.N., Jenie RI., Utomo RY., Sasmito E., Murwanti R. 2018. Caesalpinia sappan L. heartwood ethanolic extract exerts genotoxic inhibitory and cytotoxic effects. Oriental Pharmacy and Experimental Medicine, 19(1), 27-36.

Mumcuoglu M., Bagislar S., Yuzugullu H., Alotaibi H., Senturk S., et al., 2010. The ability to generate senescent progeny as a mechanism underlying breast cancer cell heterogeneity. PLOS ONE, 5(6), 1-12.

Myrianthopoulos V., Evangelou K., Vasileiou PVS., Cooks, T., Vassilakopoulos T.P., et al., 2019. Senescence and Senotherapeutics: A New Field in Cancer Therapy. Pharmacology and Therapeutics, 193, 31-49.

Nirmal NP., Rajput MS., Prasad RGSV., Ahmad M. 2015. Brazilin from Caesalpinia sappan heartwood and its pharmacological activities: A review. Asian Pac. J. Trop. Med., 8, 421-430.

Nurzijah I., Putri DDP., Rivanti E., Meiyanto E. 2012. Secang (Caesalpinia sappan L.) Heartwood Ethanolic Extract Shows Activity as Doxorubicin Co-chemotherapeutic Agent by Apoptotis Induction on T47D Breast Cancer Cells. Indonesian Journal of Cancer Chemoprevention, 3(2), 376.

Rahmawati Y., Setyawati Y., Widodo I., Ghozali A., Purnomosari D. 2017. Molecular subtypes of Indonesian breast carcinomas - Lack of association with patient age and tumor size. Asian Pacific J Canc Prev, 19(1), 161-166.

Rondão R., Seixas de Melo JS., Pina J., Melo MJ., Vitorino T., Parola AJ. 2013. Brazilwood reds: The (photo)chemistry of brazilin and brazilein. Journal of Physical Chemistry A, 117 (41), 10650-10660.

Roninson IB. 2003. Tumor Cell Senescence in Cancer Treatment. Cancer Research, 63(11), 2705-2715.

Saraste A., Pulkki K. 2000. Morphologic and biochemical hallmarks of apoptosis. Cardiovascular Research, 45(3), 528-537.

Sasaki Y., Hosokawa T., Nagai M., Nagumo S. 2007. In vitro study for inhibition of NO production about constituents of Sappan lignum. 
Biological and Pharmaceutical Bulletin, 30(1), 193-196.

Speirs CK., Hwang M., Kim S., Li W., Chang S., Varki V., Mitchell L., Schleicher S., Lu B. 2011. Harnessing the cell death pathway for targeted cancer treatment. American journal of cancer research, 1(1), 43-61.

Studencka M. Schaber J. 2017. Senoptosis: Nonlethal DNA cleavage as a route to deep senescence. Oncotarget, 8(19), 3065630671.

Tirtanirmala P., Novarina A., Utomo RY., Jenie RI., Meiyanto E. 2015. Cytotoxic and Apoptotic- inducing Effect of Fraction Containing Brazilein from Caesalpinia sappan L. and Cisplatin on T47D Cell Lines. Indonesian J Cancer Chemoprevention, 6(3), 89.

Tiwari P., Kumar A., Balakrishnan S., Kushwaha HS., Mishra KP. 2011. Silibinin-induced apoptosis in MCF7 and T47D human breast carcinoma cells involves caspase-8 activation and mitochondrial pathway. Cancer Investigation, 29(1), 12-20.

Uchida N., Suda T., Ishiguro K. 2013. Effect of Chemotherapy for Luminal A Breast Cancer. Yonago Acta Medica, 56, 51-56 